\title{
Feeding and management practices of Red Chittagong cattle in two selected upazilas of Chittagong district
}

\author{
Al Simul ${ }^{1}$, AKFH Bhuiyan ${ }^{2}$, MK Alam* $^{3}$, MM Sarkar ${ }^{4}$ and MM Rahman ${ }^{3}$ \\ ${ }^{1}$ Department of Animal Nutrition, Bangladesh Agricultural University, Mymensingh- \\ 2202; 'Department of Animal Breeding and Genetics, Bangladesh Agricultural University, \\ Mymensingh-2202; ${ }^{3}$ Animal Production and Research Division, Bangladesh Livestock Research \\ Institute, Savar, Dhaka; ${ }^{4}$ Biotechnology Division, Bangladesh Livestock Research Institute, Savar, \\ Dhaka
}

\begin{abstract}
The present study was designed to obtain existing baseline information on feeding and management practices of Red Chittagong (RC) cattle in two Upazilas of Chittagong district. The results showed that among 42 cattle owners, agriculture was the main occupation $(52.38 \%)$. The percentage of RC cattle was about $70 \%$ and concentration was higher in Anowara than that of Chandanaish upazila. Farmers of the study area supplied on an average $4.93,8.35,2.25,1.54(\mathrm{~kg} / \mathrm{d})$ of rice straw, green grass, rice polish and wheat bran respectively. About $45.24 \%, 21.43 \%, 30.95 \%$ and $2.38 \%$ farmers supplied whole and dry straw, chopped and dry straw, chopped straw soaked with water and straw with green grass respectively. About $55 \%, 14.3 \%$ and $13 \%$ of the farmers followed stall feeding (cut and carry system), grazing and stall feeding with grazing respectively for feeding green grasses. The average daily grazing period of cattle was 7.25 hours with highest and lowest 9 and 5 hours respectively daily. About $26.19 \%$ of the respondents made cattle house using tin and chatai. $81 \%$ of the cattle house had sufficient ventilation and light. The major disease outbreak in the area was FMD, which was $45 \%$ of the total disease incidence. About 36\% respondents used vaccine and $95 \%$ took help from village doctor for treatment of their cattle. Cattle rearing contributed more (about $57 \%$ ) to income generation of low income group than medium $(6.89 \%)$ and high $(8.25 \%)$ income groups. $35 \%$ respondents showed their interest to grow fodder crops and $65 \%$ of farmers were reluctant to grow fodder crops due to limitation of crop land.
\end{abstract}

Key words: : Red Chittagong cattle, feeding and management practices

Bangladesh Animal Husbandry Association. All rights reserved.

Bang. J. Anim. Sci. 2012. 41 (1): 35-40

\section{I ntroduction}

Bangladesh is a country of small and mixed farms where crop, livestock, fisheries and homestead forestry is the major components of the farming systems. The total cattle population in Bangladesh is estimated as 22.90 million (Bangladesh Economic Reviews and DLS, 2008). Most of the Bangladeshi cattle are of Bos indicus type and there are few improved varieties of cattle such as Red Chittagong Cattle (RCC) in Chittagong region, Pabna Milk Cow (PMC) in Pabna region, North Bengal Grey, Munshigonj type etc (Hossain 2005). Among them, the Red Chittagong cattle are one of the improved and promising varieties of domestic animal genetic resource. Its milk production is higher than the milk production of indigenous cattle and it's well adopted in prevailing feeding and management systems and resistant to several diseases and parasitic infestation (Ali, 1965).

But this cattle with other important animal genetic resources in Bangladesh like Local sheep, indigenous Buffalo, Assel chicken, Sorail dog etc have become endangered or at risk condition (Husain and Amin 2003). So, strategy for genetic conservation and improvement of RC cattle is highly justified for small scale dairy enterprise. Development of appropriate feeding and management system utilizing available feed resources to increase RC cattle performance is therefore, an important aspect that needs to be addressed. However, up-to-date knowledge on the state of feeding and management system of Red Chittagong cattle in their home tract is essential in order to proceed further. Red Chittagong cattle are selected for this study as feeding and 
management system of RC cattle currently being practiced by the farmers are not available. Keeping this view in mind, the present study was undertaken to study feeding system and management practices of Red Chittagong cattle followed by farmers.

\section{Materials and Methods}

Two upazilas namely Anowara and Chandanaish of Chittagong district were selected for this study. A total of fourty two (42) farmers were selected. Among them 22 farmers were from Anowara and 20 from Chandwanish. Farmers who had at least one RC cattle were involved in this study. The data were collected by interviewing cattle owners door to door using a questionnaire. The data about age, level of education, family size, farm size and annual income of the respondents were considered as primary information's of this study.

Feeding and management: The data about feeding practices includes supply of roughage and concentrate feed to cattle. It also include different feeding systems like intensive, extensive, semi extensive, individual or group feeding, with or without processing of feed etc were collected for this study. Management system included housing, disease control, vaccination and Medicare etc. were considered for this study.

\section{Statistical analysis}

All the data from two locations were analyzed with help of descriptive statistical method using Statistical Package for Social Science (SPSS). Analysis was performed to calculate number, means, percentage and standard deviation.

\section{Results and Discussion}

\section{Cattle Population}

The concentration of cattle population in Anowara and Chandanaish are presented in Table 1. The concentration of Red Chittagong (RC) cattle was higher (80\%) in Anowara upazila than that in Chandanaish (58\%). In both upazilas about $69.7 \%$ of total cattle population were RC cattle followed by Deshi (27\%) and crossbred (3.4\%). Hossain (2005) also reported higher concentration of RC cattle in Anowara, Patiya, Chandanaish and Raozan upazila of Chittagong district. The results indicated that the farmers had on an average $70.6 \%$ milking cows of RC genotype followed by $29.4 \%$ Deshi cows. No crossbred milking cow was reported in the study area.

Table1. Cattle population

\begin{tabular}{llcccccc}
\hline \multirow{2}{*}{ Animal category } & Genotypes & \multicolumn{2}{c}{ Anowara $(\mathrm{n}=22)$} & \multicolumn{2}{c}{ Chandanaish $(\mathrm{n}=20)$} & \multicolumn{2}{c}{ All area $(\mathrm{n}=42)$} \\
\cline { 2 - 8 } & /breed & No. & $\%$ & No. & $\%$ & No. & $\%$ \\
\hline \multirow{2}{*}{ Milking cow } & RCC & 14 & 87.50 & 10 & 55.56 & 24 & 70.59 \\
& Deshi & 2 & 12.50 & 8 & 44.44 & 10 & 29.41 \\
\hline \multirow{2}{*}{ Pregnant cow } & RCC & 8 & 100.00 & 5 & 83.33 & 13 & 92.85 \\
& Deshi & 0 & 0.00 & 1 & 16.67 & 1 & 7.14 \\
\hline \multirow{2}{*}{ Bull } & RCC & 3 & 100.00 & 0 & 0.00 & 3 & 50.00 \\
& Deshi & 0 & 0.00 & 3 & 100.00 & 3 & 50.00 \\
\hline \multirow{3}{*}{ Heifer } & RCC & 3 & 50.00 & 4 & 100.00 & 7 & 70.00 \\
& Deshi & 2 & 33.33 & 0 & 0.00 & 2 & 20.00 \\
& Crossbred & 1 & 16.67 & 0 & 0.00 & 1 & 10.00 \\
\hline \multirow{3}{*}{ Male calf } & RCC & 3 & 42.86 & 3 & 60.00 & 6 & 50.00 \\
& Deshi & 3 & 42.86 & 2 & 40.00 & 5 & 41.67 \\
& Crosbred & 1 & 14.29 & 0 & 0.00 & 1 & 8.33 \\
\multirow{2}{*}{ Female calf } & RCC & 5 & 100.00 & 4 & 50.00 & 9 & 69.23 \\
& Deshi & 0 & 0.00 & 3 & 37.50 & 3 & 23.08 \\
\hline Total RC cattle & Crossbred & 0 & 0.00 & 1 & 12.50 & 1 & 7.69 \\
\hline
\end{tabular}

$n$, number of farmers 


\section{Quantity of feed supplied to the animals}

The average quantity of rice straw and rice polish supplied daily to the cattle was higher in Anowara than those in Chandanaish upazila. In contrast, average daily supply of green grass and wheat bran to each cattle was lower in Anowara than those in Chandanaish upazila (Table 2). The Table also shows that on an average $2.25 \mathrm{~kg}$ rice polish and $1.54 \mathrm{~kg}$ wheat bran were supplied daily by the farmers to each cattle. Jalil et al. (1995) reported that rice straw and green grass available per cow per day were $4.03 \mathrm{~kg}$ and $11.35 \mathrm{~kg}$ respectively. They also reported that the amount of concentrate feeds like rice polish and wheat bran supplied to each cow per day were 2.17 and $0.72 \mathrm{~kg}$ respectively. The amount of rice straw and rice polish supplied to each animal are almost similar to the present study. Farmers of all areas on average, supplied $4.93 \mathrm{~kg}$ rice straw and $8.35 \mathrm{~kg}$ green grass per day to each animal irrespective of land size (Table 2). The quantity of straw and green grass was recorded based on the assumption of the farmer. The supply of rice straw increased with the increase of land size while supplied of green grass decreased with the increase of land size. There was a trend to increase concentrate supplementation with the increase of land size (Table 3 ).

Table 2. Quantity of feed ingredients supplied by the farmer to cattle

\begin{tabular}{lccc}
\hline Feeds & \multicolumn{3}{c}{ Feed supplied $(\mathrm{kg} / \mathrm{d} / \mathrm{h} \pm \mathrm{SD})$} \\
\cline { 2 - 4 } & $\begin{array}{c}\text { Anowara } \\
(\mathrm{n}=22)\end{array}$ & $\begin{array}{c}\text { Chandanaish } \\
(\mathrm{n}=20)\end{array}$ & $\begin{array}{c}\text { All areas } \\
(\mathrm{n}=42)\end{array}$ \\
\hline Rice straw & $5.18 \pm 2.79$ & $4.65 \pm 1.23$ & $4.93 \pm 2.18$ \\
Green grass & $7.00 \pm 2.37$ & $9.85 \pm 2.85$ & $8.35 \pm 2.95$ \\
Rice polish & $2.32 \pm 1.32$ & $2.17 \pm 1.13$ & $2.25 \pm 1.22$ \\
Wheat bran & $1.34 \pm 0.60$ & $1.70 \pm 0.61$ & $1.54 \pm 0.63$ \\
\hline
\end{tabular}

$\mathrm{n}$, number of farmers

\section{Method of straw feeding}

The whole rice straw under was fed to the cattle by the majority of farmers (about $45 \%$ ) in the study area (Table 4). About $21.4 \%$ farmers used chopped straw to fed their cattle. Many farmers (about 31\%) preferred to soak it with water before feeding. In fact, feeding method of straw followed by the farmers was almost similar in two areas except feeding straw mixed with green grass. In Anowara no farmer followed this practice but in Chandanaish about $2.4 \%$ of farmers fed straw mixed with green grass to their cattle. Rahman et al. (1998) reported a little variation of straw feeding that $10.5,19,32.5$ and $24.5 \%$ of the total farmers used rice straw as a dried whole straw, dried chopped straw, wet chopped straw and chopped straw + green grass respectively.

Most of the farmers followed (54.8\%) stall feeding for supplying green grass to their cattle (Table 4). About $31 \%$ of total farmers followed both stall feeding and grazing method, 15\% followed only grazing method for feeding green grasses to the cattle. The methods of green grass feeding were almost similar in both Anowara and Chandanaish upazilas. In both upazilas, $100 \%$ farmers followed group feeding for their cattle. In a previous study, Rahman et al. (1998) found that stall feeding was practiced by $1.53 \%$ farmers, while tethering and stall feeding were practiced by $41.32 \%$ farmers.

Table 3. Quantity of feed ingredients supplied by the farmer in relation to land size

\begin{tabular}{lcccc}
\hline \multirow{2}{*}{ Land size (n) } & \multicolumn{4}{c}{ Feeds supplied (kg/head/day) } \\
\cline { 2 - 5 } & $\begin{array}{c}\text { Rice } \\
\text { straw }\end{array}$ & $\begin{array}{c}\text { Green } \\
\text { grass }\end{array}$ & $\begin{array}{c}\text { Rice } \\
\text { polish }\end{array}$ & $\begin{array}{c}\text { Wheat } \\
\text { bran }\end{array}$ \\
\hline Landless (13) & 4.33 & 9.12 & 1.85 & 1.15 \\
Small (24) & 4.50 & 8.25 & 2.23 & 1.27 \\
Medium (3) & 5.00 & 8.33 & 2.25 & 1.78 \\
Large (2) & 5.87 & 7.7 & 2.67 & 1.96 \\
Average & 4.93 & 8.35 & 2.25 & 1.54 \\
\hline
\end{tabular}

$\mathrm{n}$, number of respondent; Landless (0.00-0.49 acre); Small (0.50-2.49 acre; Medium (2.50-7.49 acre); Large ( 7.50 acre and above)

\section{Grazing pattern of cattle}

Fellow land, road side, school field, play ground were used for grazing livestock. Table 5 show sthat the average grazing period was higher in Chandanaish $(8.25 \mathrm{hr} / \mathrm{d})$ than Anowara (6.58 $\mathrm{h} /$ day). The highest and lowest grazing period in Chandanaish were 10 hours and 6 hours per day respectively while in Anowara upazila, the highest and lowest grazing period were 8 hours and 4 hours per day respectively. This variation may be due to the fact that the percentage of landless farmers (35\%) in Chandanaish was higher than Anowara upazila (22.73\%). The average grazing period in two upazilas was 7.25 hours/day. Kibria (1991) in a previous study found the highest and lowest grazing period of 9.07 hours and 4.17 hours/day respectively. In a more recent study, Rahman et al. (1998) reported that the highest and lowest grazing period for cattle were 8 hours and 2 hours/day, respectively. 
Shimul et al. (2012) Bang. J. Anim. Sci. 41 (1): 35-40

Table 4. Method of feeding straw and green grass

\begin{tabular}{lcccccc}
\hline \multirow{2}{*}{ Feeding method } & \multicolumn{2}{c}{ Anowara $(\mathrm{n}=22)$} & \multicolumn{2}{c}{ Chandanaish $(\mathrm{n}=20)$} & \multicolumn{2}{c}{ All area $(\mathrm{n}=42)$} \\
\cline { 2 - 7 } & $\begin{array}{c}\text { No. } \\
\text { respondent }\end{array}$ & $\%$ & $\begin{array}{c}\text { No. } \\
\text { respondent }\end{array}$ & $\%$ & No. & respondent \\
\hline Whole straw & 10 & 45.55 & 9 & 45.00 & 19 & 45.24 \\
Chopped straw & 5 & 22.73 & 4 & 20.00 & 9 & 21.43 \\
Chopped straw soaked with water & 7 & 31.82 & 6 & 30.00 & 13 & 30.95 \\
Others (Straw + green grass) & 0 & 0.00 & 1 & 5.00 & 1 & 2.38 \\
Stall feeding & 11 & 50.00 & 12 & 60.00 & 23 & 54.76 \\
Grazing & 3 & 13.64 & 3 & 15.00 & 6 & 14.29 \\
Stall feeding with grazing & 8 & 36.36 & 5 & 25.00 & 13 & 30.95 \\
\hline
\end{tabular}

$\mathrm{n}$, number of farmers

Table 5. Duration of grazing period ( $\mathrm{hr} /$ day)

\begin{tabular}{lccc}
\hline Grazing period (hour/day) & Anowara $(\mathrm{n}=22)$ & Chandanaish $(20)$ & All areas $(\mathrm{n}=42)$ \\
\hline Grazing & $6.58(54.54)$ & $8.25(40.00)$ & $7.25(47.61)$ \\
Highest grazing period & $8(33.33)$ & $10(25.00)$ & $9(29.17)$ \\
Lowest grazing period & $4(8.33)$ & $6(12.50)$ & $5(10.42)$ \\
\hline
\end{tabular}

Figures within the parenthesis indicate the percentage of respondents

\section{Fodder production}

In the study area, 38\% respondents wanted to grow fodder and $62 \%$ respondents were reluctant to grow fodder due to lack of land (Table 6). The farmers having large land size were interested to grow fodder in their field and this trend was increasing gradually. They showed interest to grow german, dal, para, maize etc fodders. This is almost similar to the findings of Haque and Amin (1992). They reported that $35 \%$ respondents wanted to grow fodder and $65 \%$ of farmers were reluctant to grow fodder.

Table 6. Information on farmer's interest to grow fodder based on land size

\begin{tabular}{lccc}
\hline Land size & $\begin{array}{c}\text { No. } \\
\text { respondents } \\
(\mathrm{n}=42)\end{array}$ & $\begin{array}{c}\text { Want to } \\
\text { grow } \\
\text { fodder } \\
(\%)\end{array}$ & $\begin{array}{c}\text { Do not } \\
\text { want to } \\
\text { grow } \\
\text { fodder }(\%)\end{array}$ \\
\hline Land less & 13 & 15 & 75 \\
Small & 24 & 41 & 59 \\
Medium & 3 & 66.67 & 33.33 \\
Large & 2 & 100 & 0 \\
\hline \multicolumn{2}{r}{ Average } & 38.1 & 61.90 \\
\hline
\end{tabular}

$\mathrm{n}$, number of respondent; Landless (0.00-0.49 acre); Small (0.50-2.49 acre; Medium (2.50-7.49 acre); Large ( 7.50 acre and above)

\section{I nformation related to housing}

The cattle houses were made of varieties of local materials such as straw, tin, mud, chatai, and in few cases tin shed having brick wall and concrete floor (Table 7). In Anowara 32\% houses were made of straw and in Chandanaish were $45 \%$ made of tin and chatai. This may be related to the economic condition of the farmers which is much better for the farmers of Chandanaish than Anowara upazila. Housing space per household was higher in Chandanaish (100 sqft) than Anowara upazila (96 sqft). The location of the cattle house in most cases $(60 \%)$ was far from the farmer's house which is different from the findings of the Hossain (2005). He reported that in most cases cattle house were near the farmer's house. Most of cattle house were east facing in Anowara (60\%) while in Chandanaish, most of the houses were north-facing. On an average in two upazila most of the houses $(40.48 \%)$ are east-facing. Longevity of house was higher (10year) in Chandanaish than Anowara (about 5\%) which may be due to the fact the materials used for cattle house. In Chandanaish, $90 \%$ of the cattle houses had sufficient ventilation and light which is higher than that of $72 \%$ in Anowara. 
Table 7. Information related to housing

\begin{tabular}{|c|c|c|c|}
\hline \multirow[b]{2}{*}{ Aspects } & \multicolumn{3}{|c|}{$\%$ of respondents } \\
\hline & $\begin{array}{c}\text { Anowara } \\
(n=22)\end{array}$ & $\begin{array}{l}\text { Chandanaish } \\
\quad(n=20)\end{array}$ & $\begin{array}{l}\text { All area } \\
(n=42)\end{array}$ \\
\hline \multicolumn{4}{|c|}{ Materials used for house construction } \\
\hline Straw & 31.82 & 5.00 & 19.05 \\
\hline Tin & 9.09 & 25.00 & 16.67 \\
\hline Mud & 13.60 & 10.00 & 11.90 \\
\hline Building & 4.54 & 0.00 & 2.38 \\
\hline Chatai & 0.00 & 5.00 & 2.38 \\
\hline $\begin{array}{l}\text { Straw and } \\
\text { mud }\end{array}$ & 13.60 & 5.00 & 9.52 \\
\hline Tin and straw & 9.09 & 0.00 & 4.76 \\
\hline $\begin{array}{l}\text { Straw and } \\
\text { chatai }\end{array}$ & 9.09 & 5.00 & 7.14 \\
\hline $\begin{array}{l}\text { Tin and } \\
\text { chatai }\end{array}$ & 9.09 & 45.00 & 26.19 \\
\hline Area of the & & & \\
\hline $\begin{array}{l}\text { house } \\
\text { (Sq.ft.) }\end{array}$ & 96 & 100 & 98 \\
\hline \multicolumn{4}{|c|}{ Location of the house } \\
\hline $\begin{array}{l}\text { Near to bed } \\
\text { room }\end{array}$ & 40.91 & 40.00 & 40.48 \\
\hline $\begin{array}{l}\text { Far from bed } \\
\text { room }\end{array}$ & 59.09 & 60.00 & 59.52 \\
\hline \multicolumn{4}{|c|}{ Facing of the house } \\
\hline East & 59.09 & 20.00 & 40.48 \\
\hline West & 36.36 & 15.00 & 26.19 \\
\hline North & 4.55 & 55.00 & 28.57 \\
\hline South & 0.00 & 10.00 & 4.76 \\
\hline $\begin{array}{l}\text { Longevity of } \\
\text { house (year) }\end{array}$ & 4.98 & 10.60 & 7.70 \\
\hline $\begin{array}{l}\text { Sufficient } \\
\text { ventilation } \\
\text { and light }\end{array}$ & 72.00 & 90.00 & 81.00 \\
\hline
\end{tabular}

$\mathrm{N}$, number of observation

\section{Diseases of cattle and their prophylactic measures}

The most prevalent diseases of RC cattle were found foot and mouth disease (FMD), phneumonia, bloat, black quarter, diarrhoea and mastitis in the study areas (Table17). Similar observation has been reported from the study of Hossain et al. (2006). The percentage of disease occurrence was higher in Anowara than Chandanaish. Use of vaccine was higher in Chanadanaish (50\%) than Anowara (22.73). The respondents of Chandanaish (100\%) buried their dead animal whereas in Anowara about $86 \%$ respondents buried their dead animals. Rest of the farmers (13.64\% in Anowara) threw the dead animal in jungle or somewhere else. It indicates that the farmers of Chandanaish upazila are more aware than the farmers of Anowara. The reason may be the higher literacy rate of Chandanaish than Anowara. Most of the farmers claimed that they were suffering from lack of vaccine for their cattle in economic price. They were failed to contact upazila veterinarian during the diseases outbreak of their cattle. Among three seasons most of the outbreak of disease was found in rainy season (76\%) followed by $16.66 \%$ and $7.14 \%$ in summer and winter season, respectively which may be due to marshy environment and poor nutritional status.

Table 8. Information related to diseases of cattle and their prophylactic measures

\begin{tabular}{|c|c|c|c|}
\hline \multirow[b]{2}{*}{$\begin{array}{l}\text { Health care } \\
\text { practices }\end{array}$} & \multicolumn{3}{|c|}{$\%$ of farmers } \\
\hline & $\begin{array}{c}\text { Anowara } \\
(n=22)\end{array}$ & $\begin{array}{l}\text { Chandanaish } \\
(n=20)\end{array}$ & $\begin{array}{l}\text { All area } \\
(n=42)\end{array}$ \\
\hline \multicolumn{4}{|c|}{ Prevalences of diseases } \\
\hline Pneumonia & 22.72 & 20.00 & 21.42 \\
\hline FMD & 68.18 & 20.00 & 45.24 \\
\hline Mastitis & 4.55 & 0.00 & 2.38 \\
\hline $\begin{array}{l}\text { Worm } \\
\text { infestation }\end{array}$ & 13.64 & 0.00 & 7.14 \\
\hline Bloat & 9.09 & 15.00 & 11.90 \\
\hline $\begin{array}{l}\text { Black } \\
\text { quarter }\end{array}$ & 4.55 & 5.00 & 4.76 \\
\hline Diarrhoea & 9.09 & 0.00 & 4.76 \\
\hline Bat & 13.67 & 5.00 & 9.52 \\
\hline $\begin{array}{l}\text { Use of } \\
\text { vaccine }\end{array}$ & 22.73 & 50.00 & 35.71 \\
\hline \multicolumn{4}{|c|}{ System of treatment } \\
\hline $\begin{array}{l}\text { Village } \\
\text { doctor }\end{array}$ & 100.00 & 90.00 & 95.24 \\
\hline Hospital & 0.00 & 10.00 & 4.76 \\
\hline \multicolumn{4}{|c|}{ Seasonal out break of diseases } \\
\hline Summer & 9.09 & 25.00 & 16.66 \\
\hline Rainy & 86.36 & 65.00 & 76.19 \\
\hline Winter & 4.55 & 10.00 & 7.14 \\
\hline \multicolumn{4}{|c|}{ Fate of dead animal } \\
\hline Buried & 86.36 & 100.00 & 92.86 \\
\hline Thrown out & 13.64 & 0.00 & 7.14 \\
\hline
\end{tabular}

$\mathrm{n}$, number of observation

\section{Conclusion}

The percentage of RC cattle was higher in Anowara than that of Chandanaish upazila in Chattagong District. Farmers supplied rice straw, green grass, rice polish and wheat bran of their cattle for feeding, most of the farmers provided whole straw and followed stall feeding system (cut and carry system). The daily grazing period of cattle was average 7.25 hours 
in a day. Most of the respondents made cattle house using tin and chatai where $81 \%$ of the cattle house has sufficient ventilation and light. The major disease outbreak in the area was FMD. Reasonable respondents showed their interest to grow fodder crops and majority of farmers were reluctant due to limitation of crop land.

\section{References}

Ali SM (1965). A thought on cattle breeding policy for East Pakistan. In: Seminar on East Pakistan Livestock. Director of Livestock Services, East Pakistan, Dhaka, 21-34.

Haque MM and Amin MR (1992). Feeds and feeding of livestock-A study at the farming systems research site, Palima Tangail. Bangladesh Journal of Animal Science, 21: 5-10.

Hossain MM (2005). Characterrization and distribution pattern of Red Chittagong Cattle of Bangladesh. M.S. Thesis. Dept. of Animal Breeding and Genetics, Bang. Agric. Univ., Mymensingh, Bangladesh.

Hossain MM, Bhuian AKFH, Faruque $M O$ and Dev GK (2006). Characterrization and distribution pattern of Red Chittagong Cattle of Bangladesh. Prog. Agric. 17: 103-110.
Husain SS and Amin MR (2003). Genetic resource conservation and utilization: Participation maintenance or Animal Genetic Resource at rural level in Bangladesh. Workshop organized by FAO and Ministry of Livestock and Fisheries, Govt. of Bangladesh held in BLRI, Savar, Dhaka.

Jalil MA, Sarke NR, Paul DC and Khan AA (1995). Status of existing husbandry practices of dairy cattle at Manikgonj, Bangladesh. Bangladesh Journal of Animal Science, 24: 71-80.

Kibria SS (1991). Animal nutrition status in Bangladesh: past, present and future. In: Proceedings of the workshop on livestock development in Bangladesh. Bangladesh Livestock Research Institute, Savar, Dhaka, P. 94-118.

Rabbani MS, Alam MM, Ali MY, Rahman SMR and Saha BK (2004). Participation of rural people in dairy enterprise in a selected area of Bangladesh, Pakistan Journal of Nutrition, 3: 29-34.

Rahman MM, Akhter S and Hossain MM (1998). The availability of livestock feeds and feeding practices followed by the farmers of some areas of Mymensingh district. Bangladesh Journal of Animal Science, 27: 119-126. 